\title{
Responses of Solanum Lycopersicum to Organic Fertilizers Application
}

\author{
Afolayan Ezekiel Taiwo* and Akintunde Oluwabukola Oluwadamilola \\ Biology Department, Federal College of Education, Abeokuta Ogun State, Nigeria
}

*Corresponding author: Afolayan Ezekiel Taiwo, Biology Department, Federal

College of Education, Abeokuta Ogun State, Nigeria.

Received Date: August 18, 2020

Published Date: September 03, 2020

\begin{abstract}
This study compares the effects of organic manure (Plants and animals) on the performance of Solanum lycopersicum $L$. The work was conducted at the Botanical nursery, behind the Botanical Garden, Federal College of Education, Abeokuta, Ogun State, Nigeria. The study adopted Complete Randomized Block Design (CRBD) in 3 replicates. The treatments were animal manure of cow dung, poultry dung, rabbit dung and Plant manure of Gliricidia sepium. The plants characters measured include the leaf length, stem height, number of branches, number of leaves, number of flowers and fruits. Data obtained were analyzed using the Analysis of Variance (ANOVA) while means were separated with Duncan Multiple Range Test (DMRT). Results obtained showed that growth characters (number of leaves, number of branches, stem height and leaf length) and yield characters (number of flowers and fruits in Tomato) were influenced by the plant manure of Gliricidia sepium and animal manures of rabbit droppings. From the results, it was observed that Gliricidia sepium and rabbit dropping were the best manures for the cultivation of tomato.
\end{abstract}

Keywords: Solanun lycopersicum; Gliricidia sepium; Organic manure; Yield

\section{Introduction}

Tomato, (Solanun lycopersicum) is one of the most important vegetable fruit crops grown in Nigeria whose production is widespread in the country with a total annual production of more than 145,000 tons [1] and it is cultivated mainly in rural and partly in Urban area [2]. It is a flowering plant of the night shade family (Solanaceae) that is cultivated extensively for its edible fruits. Almulla et al. [3] reported that there are over ten thousand $(10,000)$ varieties of tomatoes.

Vegetables production in most parts of Africa, Nigeria inclusive, has been a backyard garden operation whereby farmers produce for their family. Because of increased demand for tomatoes, among other vegetables in Nigeria, for domestic and industrial uses, most small holder farmers have expanded and diversify vegetable production, resulting in increased cultivated hectares [4]. Tomato cul tivation in Nigeria covering mainly the coastal belt of the country up to the northern desert regions records yields of between 2.2 to $3.3 \mathrm{ha}^{-1}$ [5] is far below the world average of $27.5 \mathrm{t} \mathrm{ha}^{-1}$. This low production of tomato in Nigeria is caused by salinity, drought, excessive heat, declining soil fertility, over cultivation, over grazing, desertification etc. [4]. In addition, this is related to incidences of pests and diseases, poor crop management and shortage or lack of well adapted and high yielding varieties

Tomato plants have high requirement, they are heavy feeders, for macro nutrient elements, including potassium (k) and calcium (Ca) and some micronutrients such as iron (Fe), manganese ( $\mathrm{Mn}$ ) and Zinc (Zn) [6]. A study by Hinman, Pressan \& Sharp [7] revealed that without adequate supply of potassium and calcium for tomato plant uptake and utilization, tomato fruits will not accumulate solu- 
ble solids contents (Sugars) and will be susceptible to physiological disorders such as blossom end rot. According to Jones 2008, smaller requirements of the elements such as for dry matter portioning and fruit setting of the plants. Low soil fertility along with some of other environmental factors such as temperature, precipitation, humidity, solar radiation, wind is reported to affect tomato performance, hence its overall production [8]. And also, application of fertilizers as nutrient supplements is inevitably pertinent in increasing crop turnout in impoverished soils.

Tomatoes require a minimum of eight ( $8 \mathrm{hrs}$ ) of continuous sunlight each day. It requires three to four months (3-4) of warm, clear, fairly dry weather to produce best. Tomatoes need consistent night temperature between $55^{\circ} \mathrm{F}$ and $75^{\circ} \mathrm{F}$ to set fruits. Fruit will not colour properly when night temperature stays above $85^{\circ} \mathrm{F}$ and plant will quit growing when growing temperature go above $95^{\circ} \mathrm{F}[4,9]$. Tomatoes will thrive well on evenly moist, not too wet and not too dry. Too much water will drown the plant. Too little water will stop fruit production. Test the soil by sticking the finger into the soil and if it comes out wet, it does not require water. Prativa \& Bhattara [10] reported that almost any type of soil will grow tomatoes, but sandy loam is best for early tomatoes while compost-amended clay is ideal for late tomatoes.

Tomato is a glossy red but sometimes yellow pulpy edible fruit with a lot of seeds. It is a very important function in the diet of man. Labeled as a vegetable for nutritional purposes, tomatoes are good source of vitamin C and the phytochemical lycopene [11]. The fruits are commonly eaten raw in salads, served as a cooked vegetable, used as an ingredient of various prepared dishes and pickled. Additionally, a large percentage of the world's tomato crop is used for processing products which include canned tomatoes, tomato juice ketch up, paste and sun-dried tomatoes or dehydrated pulp [12].

Tomatoes are a good source of vitamin A, B, Potassium and vitamin C. which help the body to get rid of harmful free radicals and lowers cholesterol level in the blood which invariably prevent heart disease. Tomatoes are known to have a mineral called Chromium which works in keeping blood sugar in check. It also helps to improve the digestive system and the liver. Tomatoes are loaded with fiber which helps to prevent constipation [13]. The vitamin C in tomatoes controls the increase of stress hormones and helps the body to remain energized and healthy. Chlorogenic acid in tomato helps to protect the body form the adverse effects of cigarette smoke [14]. The lycopene in tomatoes is reported to control the growth of cancer cells especially prostate, stomach and colorectal cancer (Paswan, 2005). Tomatoes contain lycopene which is used for facial cleanser [15]. It cleanses and refreshes your skin and the vitamin $\mathrm{A}$ in tomatoes protects the hair from external damage. The vitamin $\mathrm{K}$ and calcium make the bone stay strong. The antioxidants present in tomatoes, are scientifically found to protect the body against cancer, including colon, prostate, breast, endometrial, lung and pancreatic tumors. Zeaxanthin, another flavonoid compound helps to protect eyes from age related disease in older adults by filtering harmful ultraviolet rays (Willer et al., 2005). These antioxidants also have anti-inflammatory effects on the body as it helps to fight inflammation throughout the body [16].

Organic manure can be applied to soils as compost or in their fresh state. According to Cambardella et al. [17], fresh organic materials contain higher inorganic nitrogen concentrations and have higher net nitrogen mineralization rates than composted manure. Paul \& Beauchamp [18] reported that plants treated with organic manures exhibited higher dry matter in the first growing season than fresh manure. In Africa, animal manure is applied to the soil for fertility related issues and its benefits are well documented. Nutrient content in animal manure differs because of the variations in diets of the animals, collection and storage. Manure and other waste products of livestock have been used as soil amendments for decades and were the only ways of enhancing soil productivity before mineral fertilizers were invented [19]. Goat, sheep, cattle and chicken manure are the common manure, used in the southern African regions with cattle contributing two thirds of the total amount of manure found and the remainder is contributed by sheep and goat manure.

Use of organic manure at agronomic rate for plant nutrient supply and for beneficial effects on soil physical properties is a traditional agricultural practice (Haynes \& Naidu, 2004). Over the last decade, the effects of organic manures on soil properties have received renewed attention due to an increased interest disposal of large amounts of waste being generated. Manure is a good source of macro and micronutrients [20]. Manure contains all nutrients that plants need and is high in potassium and relatively low in phosphorus and nitrogen which are the two most deficient nutrients in the soil [21].

Low yield of crop in most African countries was as a result of nutrient depletions, desertification caused by either climate change or deforestation, erosion, over cultivation, over grazing, etc.

This study aims at using ecologically friendly approach in enriching the soil and improving crop yield to combat hunger and starvation in Africa continent.

\section{Materials and Method}

This research was conducted at the Botanical Gardens, Biology Department, Federal College of Education, Abeokuta, Ogun State, South Western Nigeria located in a rain forest. Tomato seed obtained from the germplasm of National Centre for Genetics Resources and Biotechnology, Ibadan, Oyo state, Nigeria (NAGRAB). Soil which was oven-dried was bagged in empty cement bags and was laid out in a completely randomized block design with three replicates. Treatments for this experiment consists of $100 \mathrm{~g}$ of cow dung/bag, 100g of poultry manure/bag, 100g of rabbit droppings/ bag as animal manure and 500g of Gliricidia Sepium/bag as plant manure. 
These treatments were buried in the respective bagged soil for two weeks before planting. Five seeds were planted per bag. This was thinned to one per bag at two weeks after emergence. The following growth and yield characters were measured in this experiment: Stem height, Leaf length, Number of leaves, Number of branches, Number of fruits and Number of flowers.

Data obtained from these parameters were analysed using Analysis of Variance (ANOVA) while means were separated with the Duncan Multiple Range Test (DMRT).

\section{Results}

Table 1 shows the growth influence of different organic fertilizers on the stem height of Solanum lycopersicum. At 2 weeks after planting (2WAP), it was observed that tomato plants treated with Gliricidia sepium had the highest value $(40.7 \mathrm{~cm})$ and the value was significantly different $(\mathrm{p}<0.05)$ from all other treatments while the tomato plants treated with the untreated plant (control) had the least value $(10.1 \mathrm{~cm})$. The low value observed for cow dung at this time may be that the plant is not fully adjusted or that the animal remains had not fully dissolve for absorption by the plants.

At 4 WAP, the tomato plants treated with Gliricidia sepium had the highest values $(41.0 \mathrm{~cm}$ and for the plant height. This value was not significantly different $(\mathrm{p}<0.05)$ from those obtained from rabbit droppings-treated plants but was significantly different from all the other treatments. The untreated plants had the least values (16.3 $\mathrm{cm}$ ). This trend was maintained at 6 WAP. But at 8 and 10 WAP, it was observed that tomato plants treated with rabbit droppings had the highest values $(49.8 \mathrm{~cm}$ and $50.2 \mathrm{~cm}$ ) respectively. It was worthy of note that these values were higher than all the other treatments. The untreated plants had the least values throughout the time of the experiment.

The number of branches of solanum lycopersicum plants treated with different organic fertilizers was as shown in Table 2. At 2 WAP, it was observed that tomato plants treated with Gliricidia sepium had the highest value (13.4) for the number of branches while the untreated tomato plants had the least values (4.20). At 4WAP, tomato plants treated with rabbit dropping had the highest value (16.6) for the number of branches while the untreated plants had the least value (6.6). At 6WAP tomato plants treated with Gliricidia sepium (GS) had the highest values (21.2) while the untreated plants had the least. Rabbit droppings (RD) enhanced higher number of branches (39.8) at 8WAP.

There were interesting results at 10WAP with GS treated plants having the highest number of branches which was significantly higher $(\mathrm{p}<0.05)$ than all the other treatments. Cow dung (CD) had fewer numbers of branches between weeks 2 and 8 (2-8WAP) but had higher number of branches at 10WAP. It was observed that all the organic manures positively enhanced the growth in tomatoes, even though they were not absorbed at the same rate.
Table 3 depicts the growth influence of different organic fertilizers on the leaf length of solanum lycopersicum. At 2WAP, it was observed that tomato plants treated with Gliricidia sepium had the highest value $(5.78 \mathrm{~cm})$ and it was significantly different $(\mathrm{p}<0.05)$ form all other treatments while the untreated (control) plants had the least value $(4.7 \mathrm{~cm})$. At 4WAP tomato plants treated with Glioricidia sepium had the highest values $(5.8 \mathrm{~cm})$ which was significantly different $(\mathrm{p}<0.05)$ from other treatments while the CD treated tomatoes had highest leave length $(7.3 \mathrm{~cm})$ at $6 \mathrm{WAP}$ but the value was not significantly different $(\mathrm{p}<0.05)$ from GS treated plants.

At 8 WAP, tomato plants treated with poultry manure (PM) had the highest values $(9.0 \mathrm{~cm})$, this was not significantly different from $\mathrm{RD}$ treated plants but both were significantly different $(\mathrm{p}<0.05)$ from all the other treatments, while the untreated plants had the least values $(5.56 \mathrm{~cm})$. Rabbit droppings enhanced leaf length in tomatoes (9.3) at 10WAP which was significantly higher than all the other treatments. PM and GS treated plants were not significantly different $(\mathrm{p}<0.05)$ in their leaf length. The untreated plants had the least values throughout the study.

The influence of plants and animal manure on the number of leaves of solanum lycopersicum was as shown in Table 4. At 2 WAP, it was observed that tomato plants treated with Gliricidia Sepium had the highest value (34.4) for the number of leaves which is significantly different $(p<0.05)$ from all other treatments. At 4 WAP, 6WAP, 8WAP and 10 WAP, it was observed that tomato plants treated with Gliricidia sepium had the highest values (41.80, 45.0, 81,4, and $98.60)$ respectively, and it is significantly different $(p<0.05)$ from all other treatments while the untreated plants had the least values.

The cumulative number of flowers of Solanum lycopersicum treated with different organic fertilizers was as shown in Table 5. At 4 WAP, tomato plants treated with rabbit droppings had the highest number of fruits (1.8) for number of flowers. This value was significantly different $(\mathrm{p}<0.05)$ form all the other treatments. The untreated had the last number of fruits. At 6 and 8 WAP, it was observed that the tomato plants treated with cow dung (CD) had the highest value (4.2 and 6.2 respectively) and were significantly different $(\mathrm{p}<0.05)$ from other treatments. At 10 WAP, GS treated plats had the highest number of fruits which was not significantly different $(p<0.05)$ from the CD treated plants but was significantly higher than all the other treatments. At 12 WAP, the plant treated with rabbit droppings had the highest number of fruits (10.8) and it was not significantly different $(p<0.05)$ from cow dung treated plant but was significantly different from other treatments while Gliricidia sepium had the highest number of fruits at 14 WAP. The untreated (control) plants had the least number of fruits. Table 6 shows the yield influence of different organic fertilizers on Solanum lycopersicum. At 6 WAP, it was observed that tomato plants treated with cow dung and rabbit droppings had the highest numbers of fruits (2.0). This value is significantly different $(\mathrm{p}<0.05)$ from all the other treatments. At 8, 10 and 12 WAP, plants treated with rab- 
bit droppings had the highest value $(3.8,8.2$ and 13.0 respectfully)

RD treated plants (15.1). The untreated plants had the least numwhile the plants treated with GS had the highest number of fruits ber of fruits throughout the period of the study.

(16.2) at 14 WAP but not significantly different $(p<0.05)$ from the

Table 1: Effects of organic Fertilizers on plant height of Solanum lycopersicum.

\begin{tabular}{|c|c|c|c|c|c|}
\hline Treatments & $\mathbf{2}$ WAP & $\mathbf{4}$ WAP & $\mathbf{6 W A P}$ & $\mathbf{8}$ WAP & $\mathbf{1 0}$ WAP \\
\hline CD & $20.12 \pm 0.87^{\mathrm{j}}$ & $24.94 \pm 1.97^{\mathrm{hlj}}$ & $37.04 \pm 2.34^{\text {ghij }}$ & $39.90 \pm 2.0^{\text {cdef }}$ & $43.90 \pm 2.00^{\text {def }}$ \\
\hline PM & $30.48 \pm 0.87^{\text {fi }}$ & $32.04 \pm 9.73^{\text {fgh }}$ & $38.44 \pm 0.77^{\text {efgh }}$ & $42.0 \pm 5.54^{\text {abcd }}$ & $47.1 \pm 11.14^{\text {abc }}$ \\
\hline RD & $32.70 \pm 5.45^{\text {bcdef }}$ & $40.56 \pm 9.04^{\text {abcde }}$ & $42.0 \pm 2.34^{\text {abcde }}$ & $49.82 \pm 6.46^{\text {a }}$ & $50.2 \pm 5.67^{\text {a }}$ \\
\hline GS & $40.72 \pm 3.544^{\text {abcde }}$ & $41.0 \pm 3.51^{\text {abcde }}$ & $42.92 \pm 2.37^{\text {abcd }}$ & $47.76 \pm 5.12^{\text {abc }}$ & $48.36 \pm 5.41^{\text {abc }}$ \\
\hline CT & $10.12 \pm 0.87^{\mathrm{k}}$ & $16.26 \pm 0.75^{\text {jkl }}$ & $23.16 \pm 2.5^{\mathrm{kl}}$ & $27.5 \pm 2.79^{\text {ghi }}$ & $30.68 \pm 2.9^{\text {ghi }}$ \\
\hline
\end{tabular}

Values are means of three (3) replications. values represented by the same letter along the column are not significantly different. Cow dung (CD), Poultry manure (PM), Rabbit droppings (RD), Gliricidia sepium (GS), Control (CT,) WAP represent the weeks after planting.

Table 2: Effects of Organic fertilizer on the number of branches of Solanum lycopersicum.

\begin{tabular}{|c|c|c|c|c|c|}
\hline \multirow{2}{*}{ Treatment } & \multicolumn{5}{|c|}{ Weeks after Planting (WAP) } \\
\cline { 2 - 6 } & $\mathbf{2}$ & $\mathbf{4}$ & $\mathbf{6}$ & $\mathbf{8}$ & $\mathbf{1 0}$ \\
\hline CD & $6.20 \pm 0.37^{\mathrm{c}}$ & $9.40 \pm 0.87^{\mathrm{b}}$ & $12.60 \pm 0.24^{\mathrm{c}}$ & $29.90 \pm 2.00^{\text {fghij }}$ & $41.60 \pm 0.51^{\mathrm{b}}$ \\
\hline PM & $6.80 \pm 0.48^{\mathrm{c}}$ & $10.00 \pm 0.00^{\mathrm{b}}$ & $12.80 \pm 0.86^{\mathrm{c}}$ & $32.0 \pm 5.54^{\text {cdefg }}$ & $35.80 \pm 3.22^{\mathrm{c}}$ \\
\hline RD & $11.80 \pm 0.8^{\mathrm{b}}$ & $16.60 \pm 0.51^{\mathrm{a}}$ & $19.20 \pm 1.65^{\mathrm{b}}$ & $39.82 \pm 6.46^{\mathrm{a}}$ & $40.20 \pm 1.95^{\mathrm{b}}$ \\
\hline GS & $13.40 \pm 2.1^{\mathrm{a}}$ & $16.00 \pm 3.16^{\mathrm{a}}$ & $21.20 \pm 1.01^{\mathrm{a}}$ & $37.76 \pm 5.12^{\text {abc }}$ & $44.20 \pm 1.46^{\mathrm{a}}$ \\
\hline CT & $4.20 \pm 0.37^{\mathrm{d}}$ & $6.60 \pm 0.4^{\mathrm{c}}$ & $7.20 \pm 1.65^{\mathrm{d}}$ & $10.40 \pm 3.45^{\mathrm{k}}$ & $16.40 \pm 0.45^{\mathrm{d}}$ \\
\hline
\end{tabular}

Values are means of three (3) replicates. Values represented by the same letter along the column are not significantly different at $p<0.05$. Cow dung (CD), Poultry manure (PM), Rabbit droppings (RD), Gliricidia sepium (GS), Control (CT), WAP = weeks after planting.

Table 3: Leaf length of Solanum lycopersicum as Influenced by Organic Manure.

\begin{tabular}{|c|c|c|c|c|c|}
\hline \multirow{2}{*}{ Treatment } & \multicolumn{5}{|c|}{ Weeks after Planting (WAP) } \\
\cline { 2 - 6 } & $\mathbf{4}$ & $\mathbf{4}$ & $\mathbf{6}$ & $\mathbf{8}$ & $\mathbf{1 0}$ \\
\hline CD & $5.44 \pm 0.72^{\text {bcde }}$ & $5.68 \pm 0.39^{\text {bcdef }}$ & $7.26 \pm 0.47^{\text {abcde }}$ & $7.76 \pm 0.31^{\mathrm{c}}$ & $7.78 \pm 0.25^{\mathrm{c}}$ \\
\hline PM & $5.06 \pm 0.11^{\mathrm{e}}$ & $5.91 \pm 0.35^{\text {bcdef }}$ & $6.72 \pm 0.46^{\text {cdefg }}$ & $8.95 \pm 0.22^{\text {ab }}$ & $9.18 \pm 0.16^{\text {abc }}$ \\
\hline RD & $5.28 \pm 0.05^{\text {de }}$ & $6.76 \pm 0.44^{\text {abcde }}$ & $6.94 \pm 0.33^{\text {bcdef }}$ & $8.90 \pm 0.17^{\text {ab }}$ & $9.28 \pm 0.13^{\mathrm{a}}$ \\
\hline GS & $5.78 \pm 0.41^{\text {abcde }}$ & $6.78 \pm 0.39^{\text {abcde }}$ & $7.24 \pm 0.58^{\text {abcde }}$ & $8.36 \pm 0.61^{\text {bc }}$ & $8.84 \pm 0.41^{\text {abc }}$ \\
\hline CT & $4.68 \pm 0.25^{\text {ef }}$ & $5.14 \pm 0.08^{\mathrm{b}}$ & $5.34 \pm 0.05^{\text {ijk }}$ & $5.56 \pm 0.27^{\text {d }}$ & $6.72 \pm 0.31^{\mathrm{f}}$ \\
\hline
\end{tabular}

Values are means of three (3) replicates. Values represented by the same letter along the column are not significantly different at $p<0.05$. Cow dung $(\mathrm{CD})$, Poultry manure (PM), Rabbit droppings (RD), Gliricidia sepium (GS) and Control (CT) are the treatments used. WAP = weeks after planting.

Table 4: Influence of plants and animals' manure on the number of leaves of Solanum lycopersicum.

\begin{tabular}{|c|c|c|c|c|c|}
\hline Treatment & 2 WAP & 4 WAP & 6WAP & $\mathbf{8}$ WAP & 10 WAP \\
\hline CD & $16.00 \pm 1.76^{\text {cd }}$ & $21.80 \pm 5.14^{\mathrm{d}}$ & $33.00 \pm 4.01^{\text {cde }}$ & $45.40 \pm 5.72^{\mathrm{d}}$ & $69.60 \pm 2.85^{\mathrm{c}}$ \\
\hline PM & $27.40 \pm 8.00^{\mathrm{c}}$ & $32.20 \pm 2.89^{\mathrm{c}}$ & $37.60 \pm 11.2^{\text {cd }}$ & $55.20 \pm 6.09^{\mathrm{c}}$ & $70.80 \pm 6.36^{\mathrm{c}}$ \\
\hline RD & $30.20 \pm 4.24^{\mathrm{b}}$ & $39.40 \pm 19.1^{\mathrm{ab}}$ & $42.00 \pm 8.74^{\mathrm{a}}$ & $76.00 \pm 3.91^{\mathrm{b}}$ & $97.2 \pm 5.95^{\mathrm{ab}}$ \\
\hline GS & $34.40 \pm 6.29^{\mathrm{a}}$ & $41.80 \pm 3.37^{\mathrm{a}}$ & $45.00 \pm 17.2^{\mathrm{a}}$ & $81.40 \pm 7.41^{\mathrm{a}}$ & $98.60 \pm 6.23^{\mathrm{a}}$ \\
\hline CT & $10.40 \pm 0.92^{\mathrm{e}}$ & $16.60 \pm 5.32^{\mathrm{e}}$ & $20.60 \pm 19.3^{\text {defg }}$ & $23.40 \pm 6.01^{\mathrm{e}}$ & $37.50 \pm 5.95^{\mathrm{d}}$ \\
\hline
\end{tabular}

Values are means of three (3) replicates. Values represented by the same letter along the column are not significantly different at $p<0.05$. Cow dung (CD), Poultry manure (PM), Rabbit droppings (RD), Gliricidia sepium (GS) and Control (CT). WAP = weeks after planting.

Table 5: Effects of Organic fertilizer on the cumulative number of flowers of Solanum lycopersicum.

\begin{tabular}{|c|c|c|c|c|c|c|}
\hline Treatment & $\mathbf{4}$ WAP & $\mathbf{6}$ WAP & $\mathbf{8 W A P}$ & $\mathbf{1 0}$ WAP & $\mathbf{1 2}$ WAP & $\mathbf{1 4}$ WAP \\
\hline CD & $1.40 \pm 0.82^{\mathrm{b}}$ & $4.20 \pm 2.31^{\mathrm{a}}$ & $6.20 \pm 2.29^{\mathrm{a}}$ & $8.00 \pm 0.72^{\mathrm{a}}$ & $10.40 \pm 0.86^{\mathrm{ab}}$ & $14.6 \pm 1.32^{\mathrm{cde}}$ \\
\hline PM & $0.00 \pm 0.00^{\mathrm{d}}$ & $1.00 \pm 1.00^{\mathrm{d}}$ & $4.20 \pm 0.80^{\mathrm{c}}$ & $6.00 \pm 1.28^{\mathrm{c}}$ & $9.80 \pm 0.66^{\mathrm{bcd}}$ & $14.2 \pm 2.27^{\text {cde }}$ \\
\hline RD & $1.80 \pm 0.48^{\mathrm{a}}$ & $3.00 \pm 1.50^{\mathrm{b}}$ & $5.20 \pm 1.65^{\mathrm{b}}$ & $7.20 \pm 0.35^{\mathrm{b}}$ & $10.80 \pm 1.59^{\mathrm{ab}}$ & $15.8 \pm 1.24^{\mathrm{ab}}$ \\
\hline GS & $1.00 \pm 1.00^{\mathrm{c}}$ & $1.40 \pm 0.83^{\mathrm{d}}$ & $4.60 \pm 1.28^{\mathrm{c}}$ & $8.20 \pm 0.91^{\mathrm{a}}$ & $9.40 \pm 0.59^{\mathrm{bcd}}$ & $17.00 \pm 0.38^{\mathrm{a}}$ \\
\hline CT & $0.00 \pm 0.00^{\mathrm{d}}$ & $1.00 \pm 1.24^{\mathrm{c}}$ & $3.80 \pm 2.41^{\mathrm{d}}$ & $5.00 \pm 1.58^{\mathrm{d}}$ & $7.40 \pm 0.57^{\mathrm{e}}$ & $9.4 \pm 2.31^{\mathrm{fg}}$ \\
\hline
\end{tabular}

Values are means of three (3) replicates. Values represented by the same letter along the column are not significantly different at $p<0.05$. Cow dung (CD), Poultry manure (PM), Rabbit droppings (RD), Gliricidia sepium (GS), Untreated (CT), WAP = weeks after planting. 
Table 6: Cumulative number of fruits of Solanum lycopersicum as influenced by different organic fertilizers applications.

\begin{tabular}{|c|c|c|c|c|c|}
\hline Treatment & $\mathbf{6}$ WAP & $\mathbf{8}$ WAP & $\mathbf{1 0}$ WAP & 12 WAP & 14 WAP \\
\hline CD & $2.00 \pm 1.22^{\mathrm{a}}$ & $3.40 \pm 1.60^{\mathrm{ab}}$ & $6.60 \pm 1.53^{\mathrm{b}}$ & $10.80 \pm 1.35^{\mathrm{b}}$ & $14.00 \pm 1.5^{\mathrm{ab}}$ \\
\hline PM & $0.00 \pm 0.00^{\mathrm{c}}$ & $2.20 \pm 0.80^{\mathrm{c}}$ & $5.60 \pm 1.07^{\mathrm{c}}$ & $8.20 \pm 0.91^{\mathrm{c}}$ & $12.60 \pm 0.57^{\mathrm{c}}$ \\
\hline RD & $2.00 \pm 1.24^{\mathrm{a}}$ & $3.80 \pm 2.41^{\mathrm{a}}$ & $8.20 \pm 0.91^{\mathrm{a}}$ & $13.00 \pm 0.63^{\mathrm{a}}$ & $15.10 \pm 0.37^{\mathrm{a}}$ \\
\hline GS & $1.00 \pm 1.00^{\mathrm{b}}$ & $2.80 \pm 1.82^{\mathrm{c}}$ & $5.80 \pm 1.24^{\mathrm{c}}$ & $10.40 \pm 1.21^{\mathrm{b}}$ & $16.20 \pm 0.41^{\mathrm{a}}$ \\
\hline CT & $0.00 \pm 0.00^{\mathrm{c}}$ & $1.80 \pm 0.48^{\mathrm{d}}$ & $2.80 \pm 0.66^{\mathrm{d}}$ & $5.80 \pm 0.66^{\mathrm{d}}$ & $7.00 \pm 0.35^{\mathrm{d}}$ \\
\hline
\end{tabular}

Values are means of three (3) replicates. Values represented by the same letter along the column are not significantly different at $p<0.05$. Cow dung (CD), Poultry manure (PM), Rabbit droppings (RD), Gliricidia sepium (GS), Untreated (CT), WAP = weeks after planting.

\section{Discussion}

The stem height, number of branches, number of leaves, number of flowers, number of fruits and the leaf length of Solanum lycopersicum influenced by different organic fertilizers were investigated. The results presented in the tables revealed significant main effects of organic fertilizers on the growth of Solanum Lycopersicum. Plants height and other growth parameters were influenced by the plants manure (Gliricidia sepium) from 2WAP till the end of the experiment. This was in line with the report of Zaharah et al. [22], who opined that the releases of $\mathrm{N}, \mathrm{P}$ and $\mathrm{K}$ were rapid during the first 10 days and slower thereafter. About $60 \%$ of the $\mathrm{N}$ was lost within 10 days and a total of $76 \%$ of the original $N$. This might be due to the fact that the leaves of this plant decay fast and it is readily absorbable.

Rabbit droppings also influenced the plants height. Similar observations were made for the number of branches, number and length of leaves. This may be due to the fact that manure is a good source of macro and micronutrients, and manure contains all nutrients that plants need which is high in potassium, phosphorus and nitrogen [20]. Okoroafor et al. [23] reported that animal droppings gave the highest mean stem growth in maize throughout the time of the experiment.

Number of fruits and flowers were influenced by the applications of both plants and animal manures. The results of this work were also supported by other worker like Windham (1969) who opined that organic manure like poultry droppings, rabbit droppings etc. improve the structure of the soil thereby increasing the vegetative growth as well as the size and number of fruits. Also, Mbah [24] found that poultry, cow dung and other animal manures increased uptake of $\mathrm{k}, \mathrm{Ca}$ and $\mathrm{Mg}$ by maize because these wastes increased soil $\mathrm{OM}, \mathrm{N}$ and cation exchange significantly. The higher values reported for number and length of leaves, plants height and number of branches were consistent with the higher yield values in both plants and animal manures [25].

The growth effects of cow dung on the tomatoes plants were low at the early stage until after 6 weeks of planting when the plants' growth and yield characters were influenced by CD. This result corroborates the findings of Ewulo et al. [25] who reported that CD treatments increased growth and fruit yield parameters of pepper such as numbers of leaves, plant height, number of branches, number and weight of fruits significantly $(\mathrm{p}<0.05)$.

Rabbit droppings enhanced the number of flowers and fruits (Tables 5 and 6). The result of these findings is in line with Tourte [26], who reported that there is significant influence of rabbit droppings on Solanum lycopersicum because of their high N.P.K values against another animal manure.

\section{Conclusion}

This study shows that the use of plant and animal manure improves the chemical and physical characteristics of the soil, thereby increasing the growth and yield characters of tomatoes. The applications of organic manure highly increase plant height, number and length of leaves, number of branches, number of flowers and fruits of tomatoes. Among the organic manure used as treatments in this research, Gliricidia sepium and rabbits' droppings significantly enhanced both the growth and yield of tomatoes.

\section{Recommendation}

It has been shown that tomato plants that were treated with rabbit droppings and plant manure of Gliricidia sepium produced large number of fruits. These manures are cheap, easy to come by, ecologically friendliness and may increase farmers' returns. In view of these benefits, these manures are recommended for farmers and Government.

\section{Acknowledgement}

None.

\section{Conflict of Interest}

No conflict of interest.

\section{References}

1. Mushobozi WL (2010) Good agricultural practices (GAP) on horticultural production for extension staff in Tanzania. training manual TAO GAP Working paper serves 13: 175 .

2. Putter H, MJ Van Koesveld, CLM de viser (2001) Overview of the vegetable sector in Tanzania.

3. Almulla L, NR Bhat, VS Lekha, B Thomas, P Geoge, et al. (2012) Effect of Three organic fertilizer formulations on growth and yield of cherrytomatoes, under Soilless organic greenhouse production system. Er J Sci res 80: 281-288, 
4. Minja RR, J Ambrose, A Ndee, IS Surai, CO Ojeweo (2011) Raising improved tomato varieties for eastern Tanzania. Afri J Herticultural Sci 4: 24-30.

5. Babajide PA, TB Salami (2012) Effect of integrated nutrient management approach onsoil chemical and physical properties and performance of tomato under mildly acidic alfisol conditions. Int J Applied Agric Agriculture Res 8: 91-98.

6. Abbasi PA, JA I-Dahmanni, F Sahin, HAJ Hotink, SA Miller (2002) Effects of court amendments on disease severity and yield of tomato in conventional and organic production systems. plant disease 86: 156161.

7. Hinman JA, Pressan, H Sharp (2012) Resource guide to organic and sustainable vegetable Production.

8. Akanni DI, SO Ojeniyi (2008) Residual effect of goat and poultry manure on soil properties nutrient content and yield of amaranthus in southwest Nigeria. Res J Agron 2(2): 44-47.

9. Idowu GA, RO Oyewale, ST Yusuf, AS Isah, LY Bello (2013) Effect of phosphorus application on growth, yield and yield components of snake tomato (Trichosanthes cucumerina L.). world J Agric Sci 1: 88-93.

10. Prativa KC, BP Bhattara (2011) Effect of integrated nutrient management on the growth, yield andsoil nutrient status in tomato. Nepal J Science and technology 12: 23-28.

11. Okalebo JR, KW Gathua, P Woomer (2002) Laboratorymethod of soil and plant analysis. A working manual. 2nd Edi. ISBF-CIAJ, Nairobi, Kenya, page 126.

12. Mehdizadeh MEJ, Darband H, Naserir Rad, A Tobeh (2013) Growth and yield of tomatoes as influenced by different organic fertilizers. Int J Agron Plant prod 4: 734-738.

13. Tonfack LB, A Bernadac, F Youmbi, VP Mbou Apouognigni, M Ngueguim, et al. (2009) Impart of organic and inorganic fertilizers on tomato vigour yield and fruit composition under tropical andosol soil conditions. fruits 64: 167-177.

14. Salan MA, Siddique, MA Rachin, MA Rahman, MG Saha (2010) Quality of tomato as influenced by boron and zinc under different levels of N.P.K fertilizers Bangladesh. J Agric Res 35: 475-488.
15. Ryals OT, Kerry AT (2002) Fertilizers and their uses in India National Development Centre Bombay. Pp. 142-149.

16. Pretty, Hinne (2001) A comparison of Niacin, Lutein Zeaxaithin, Lyeopene and Carotene content in Solanum lycopersicun. Journ Hered 172: $14-35$.

17. Cambardella, Gulchard, Brook (2003) Growth and phosphorus accumulation in tomato cultivars. Journal of plant nutrition 7(11): 1651.

18. Paul, Beauchamp (2007) Nutriient compositn of manure. Agro biology 5: 25-30.

19. Lupurayi TU (2000) Some factors affecting flower production in the tomato. J Hort Sci 28: 207-209.

20. Madison N, Stapleton U, Ans B (2002) A comparison of thiamine, niarin and riboflavin content in dipoid and tetraploid platns Jour Hered 44: 149-154.

21. Okeh, Asiegbu (2010) Evaluation of the chemical composition of manure from different organic wastes 12: 1- 47.

22. Zaharah AR, Sharifuddin HAH, Anular R, Bah AR, Mwange KNk, et al. (1998) Nitrogen Fixation by Gliricidia sepium: Decomposition of its Leaves in Soil and Effects on Sweet-Corn Yields. International Nuclear Information System 148: 96-125.

23. Okoroafor IB, Okelola EO, Edeh ON, Emehute VC, Onu CN, et al. (2013) Effect of Organic Manure on the Growth and Yield Performance of Maize in Ishiagu, Ebonyi State, Nigeria. IOSR Journal of Agriculture and Veterinary Science 5(4): 28-31.

24. Mbah CN (2006) Influence of organic wastes on plant growth parameters and nutrient uptake by maize (Zea mays L.). Nigeria J Soil Sci 16: 104108.

25. Ewulo BS, Hassan KO, SO Ojeniyi (2007) Comparative Effect of Cowdung Manure on Soil and Leaf Nutrient and Yield of Pepper. International Journal of Agricultural Research 2: 1043-1048.

26. Tourte CR, Fontes, Panlo (2006) Growth and phosphorus accumulation in tomato cultivars. Journal of plant nutrition. Pp. 1778. 